\title{
Whole-lake algal responses to a century of acidic industrial deposition on the Canadian Shield
}

\author{
Rolf D. Vinebrooke, Sushil S. Dixit, Mark D. Graham, J ohn M. Gunn, \\ Yu-Wei Chen, and Nelson Belzile
}

\begin{abstract}
A century of cultural acidification is hypothesized to have altered algal community structure in boreal lakes. To date, this hypothesis has remained untested because of both the lack of data predating the onset of industrial pollution and incomplete estimates of whole-lake algal community structure. High-pressure liquid chromatography (HPLC) of sedimentary pigments was used to quantify whole-lake algal responses to acid deposition in six boreal lakes located in Killarney Park, Ontario, Canada. Concomitant significant increases in chlorophyll and carotenoid concentrations, diatom-inferred lake acidity, and metal levels since 1900 suggested that algal abundances in four acidified lakes and one small, circumneutral lake were enhanced by aerial pollution. An alternate explanation is that increased acidity and underwater light availability in the acidified lakes shifted algal abundance towards phytobenthos and deepwater phytoplankton, whose pigment signatures were better preserved in the sediments. Taxonomically diagnostic pigment stratigraphies were consistent with shifts in algal community structure towards filamentous green phytobenthos and deepwater phytoflagellates in the acidified lakes. Our findings suggest that decades of aerial pollution have altered the base of foodwebs in boreal lakes, potentially rendering them less resilient to other environmental stressors.
\end{abstract}

Résumé : L'acidification causée par l'activité humaine depuis un siècle a, croit-on, modifié la structure des communautés d'algues dans les lacs boréaux. Cette hypothèse n'a pas encore été éprouvée, tant à cause du manque de données qui datent d'avant la pollution industrielle qu'à cause des estimations incomplètes de la structure de la communauté d'algues à l'échelle de lacs entiers. La chromatographie liquide à haute pression (HPLC) des pigments des sédiments nous a permis d'évaluer quantitativement la réponse des algues à l'échelle lacustre aux retombées acides dans 6 lacs boréaux du parc de Killarney en Ontario, Canada. Des accroissements significatifs et concomitants des concentrations de chlorophylle et de caroténoïdes, de l'acidité du lac déterminée d'après les diatomées et des concentrations de métaux depuis 1900 laissent croire qu'une augmentation de l'abondance des algues a été favorisée par la pollution aérienne dans 4 lacs acidifiés et un petit lac à eau à peu près neutre. Une explication de rechange serait que la hausse de l'acidité et la disponibilité accrue de la lumière dans l'eau des lacs acides aient plutôt avantagé le phytobenthos et le phytoplancton profond, dont les signatures pigmentaires se sont mieux conservées dans les sédiments. La stratigraphie des pigments d'intérêt taxonomique dans les lacs acidifiés est compatible avec un changement de dominance dans la structure de la communauté d'algues qui privilégie les algues vertes filamenteuses benthiques et les phytoflagellés d'eau profonde. Des décennies de pollution aérienne ont sans doute modifié la base des réseaux alimentaires dans les lacs boréaux, ce qui les rend potentiellement moins résilients aux autres sources environnementales de stress.

[Traduit par la Rédaction]

\section{Introduction}

There is increasing concern over the consequences of anthropogenic stresses and loss of biodiversity on the productivity and stability of boreal lakes (Schindler 1998). Acid rain, climate warming, and increased ultraviolet-B (UVB; 280-320 nm wavelength) irradiance impact biodiversity of naturally species-poor communities in boreal lakes, which may reduce or destabilize vital ecosystem functions, such as primary production (Schindler 1995). For example, experimental acidification of boreal lakes caused significant loss of algal species, resulting in increased temporal variability of primary production (Turner et al. 1995; Findlay et al. 1999). However, primary production is not suppressed by

Received 20 June 2001. Accepted 27 February 2002. Published on the NRC Research Press Web site at http://cjfas.nrc.ca on 6 April 2002.

J16416

R.D. Vinebrooke ${ }^{1}$ and M.D. Graham. Department of Biology, University of Regina, Regina, SK S4S 0A2, Canada.

S.S. Dixit. Paleoecological Environmental Assessment and Research Laboratory, Department of Biology, Queen's University, Kingston, ON K7L 3N6, Canada.

J.M. Gunn. Ontario Ministry of Natural Resources, Cooperative Freshwater Ecology Unit, Laurentian University, Sudbury, ON P3E 2C6, Canada.

Y.-W. Chen and N. Belzile. Department of Chemistry and Biochemistry, Laurentian University, Sudbury, ON P3E 2C6, Canada.

${ }^{1}$ Corresponding author (e-mail: rolf.vinebrooke@uregina.ca). 
experimental acidification because acid-tolerant species compensate for the extirpation of acid-sensitive competitors (Findlay et al. 1999; Klug et al. 2000). Nevertheless, algal abundance in boreal lakes may have been adversely affected by chronic exposure to several decades of cultural acidification and biological impoverishment, but such impacts have not been verified.

Boreal lakes show consistent changes in algal community structure during cultural and experimental acidification (Schindler et al. 1991). In general, phytoplankton assemblages shift from chrysophytes, diatoms, and cyanobacteria towards large dinoflagellates (Findlay et al. 1999). In addition, deepwater blooms of hypolimnetic phytoflagellates can flourish in acidified lakes (Findlay and Kasian 1990), possibly as a result of loss of light-attenuating dissolved organic carbon (DOC) from the water column (Schindler et al. 1996; Yan et al. 1996). Whole-lake experiments (Findlay et al. 1999) and lake surveys (Vinebrooke 1996; Vinebrooke and Graham 1997) show that phytobenthos assemblages shift from cyanobacteria to filamentous green algae and diatoms with increasing water acidity. Benthic mats of filamentous green algae often proliferate and detach to form floating clouds, termed metaphyton, that shift primary production in the littoral zone from the phytobenthos to the overlying water column during late summer (Turner et al. 1995; Vinebrooke et al. 2001). Thus, anthropogenic acidification can cause long-term alteration of algal communities by changing their abundance, taxonomic composition, and spatial distribution in boreal lakes.

Paleolimnological techniques are being increasingly used to reconstruct the chemical and biological histories of experimentally and culturally acidified lakes. In the Sudbury area, sedimentary stratigraphies of diatom valves and chrysophyte scales have been used to infer long-term changes in lake water chemistry in response to changes in industrial acid deposition (Dixit et al. 1992a, 1992b, 2001). Similarly, analysis of sedimentary pigments showed that algal responses to experimental acidification were associated with complex changes in $\mathrm{pH}, \mathrm{DOC}$, and light in experimentally acidified Lake 302 (Leavitt et al. 1999). Calibration studies using long-term phytoplankton records have shown that sedimentary pigment concentrations are significantly related to phytoplankton abundance, and function as reliable indicators of whole-lake algal abundance and gross community composition (Leavitt et al. 1997, 1999). Therefore, in the absence of long-term environmental data, sedimentary pigment stratigraphies provide the only means of documenting the responses of primary producers in Canadian Shield lakes to decades of acid deposition.

Here we report on evidence from sedimentary pigment stratigraphies indicating that nearly a century of industrial activity has altered whole-lake algal-community structure in five of six boreal lakes located in a region of high acid deposition. Pigment stratigraphies were used to determine if long-term cultural acidification of boreal lakes reduced or destabilized whole-lake algal abundance and taxonomic composition. This expectation was based on the welldocumented negative effects of anthropogenic acidification on algal diversity (Turner et al. 1995; Vinebrooke and Graham 1997; Findlay et al. 1999), and consequently, how a major loss of species can impair a community's ability to acquire resources and tolerate environmental stress and variability (Schindler 1995).

\section{Material and methods}

\section{Study area}

Killarney Provincial Park is a wilderness area impacted by industrial emissions from nearby ( $\sim 50 \mathrm{~km}$ northwest) Sudbury, Ont. (Fig. 1). Industrial activities began in the Sudbury area at the turn of the 20th century and accelerated thereafter with the construction of mining smelters nearby following World War I (Howard-White 1963). Industrial emission of sulphur dioxide increased to over 2.5 million tonnes per year by the 1960s. As a consequence, several lines of evidence show that lakes in central Ontario, including Killarney lakes, experienced substantial chemical and biological damage during this period (Jeffries 1997). Subsequently, 50-90\% reductions of regional $\mathrm{SO}_{2}$ and trace metal emissions over the last two decades have resulted in chemical recovery in many lakes, but biological recovery in only a few lakes (Keller et al. 1992; Snucins et al. 2001). Currently, pollutant levels over Killarney lakes are mainly attributable to continentwide (Canada-U.S.A.) industrial activities and combustion of fossil fuels (Jeffries 1997).

The study lakes are situated along the La Cloche Mountain Range, which is characterized by a series of geological formations (Fig. 1). Poor acid-neutralizing capacities (ANC) and low concentrations of DOC characterize the highelevation lakes, because their catchments consist of coniferous forests, thin podzolic soils, and orthoquartzite bedrock. At lower elevations, lakes have higher ANC and DOC levels because of higher bedrock mineralization rates and mixed forests and wetlands in their catchments. Well-buffered, mesotrophic lakes occur on predominantly calcareous bedrock located in the northwestern region of the park. Regional differences in geology and other catchment characteristics influence the water chemistries of the six study lakes (Snucins and Gunn 1998).

Six study lakes were selected to span gradients of lake acidity and recovery rates (Fig. 1; Table 1). Acid Lake and OSA Lake were included as highly acidified ( $>1$ diatominferred $\mathrm{pH}$ unit decline since 1880; Dixit et al. 1992a) clearwater lakes that have shown slow recovery trajectories ( $\sim .1$ pH unit.10 year ${ }^{-1}$ since 1980; Snucins et al. 2001). Acid Lake is located on a quartzite ridge with a catchment consisting of mixed forest ( $300 \mathrm{ha})$, exposed bedrock $(\sim 100 \mathrm{ha})$, and upstream lakes, ponds, and wetlands ( 40 ha). OSA Lake is situated in a lowland underlain by bedrock consisting of siltstone and sandstone, and surrounded by quartzite ridges covered $\sim 50 \%$ by coniferous forests. Bell Lake and George Lake were less acidified $(<1$ diatom-inferred $\mathrm{pH}$ unit decline since 1880; Dixit et al. $1992 a, 1992 b, 2001)$, and have exhibited relatively fast recovery rates $\left(\sim 0.5 \mathrm{pH}\right.$ unit $\cdot 10$ year $^{-1}$ since 1980 ; Snucins et al. 2001). Bell Lake is situated between high outcrops of white orthoquartzite on the northwestern shore and bedrock consisting of metamorphosed sedimentary rock and granite on the southeastern shore. The catchment of Bell Lake consists primarily of mixed forest $(\sim 75 \%)$ and upstream lakes 
Fig. 1. Location of the paleolimnological study lakes in Killarney Park, Ont. Other major water bodies, waterways, and watershed boundaries (solid black lines) are also shown.

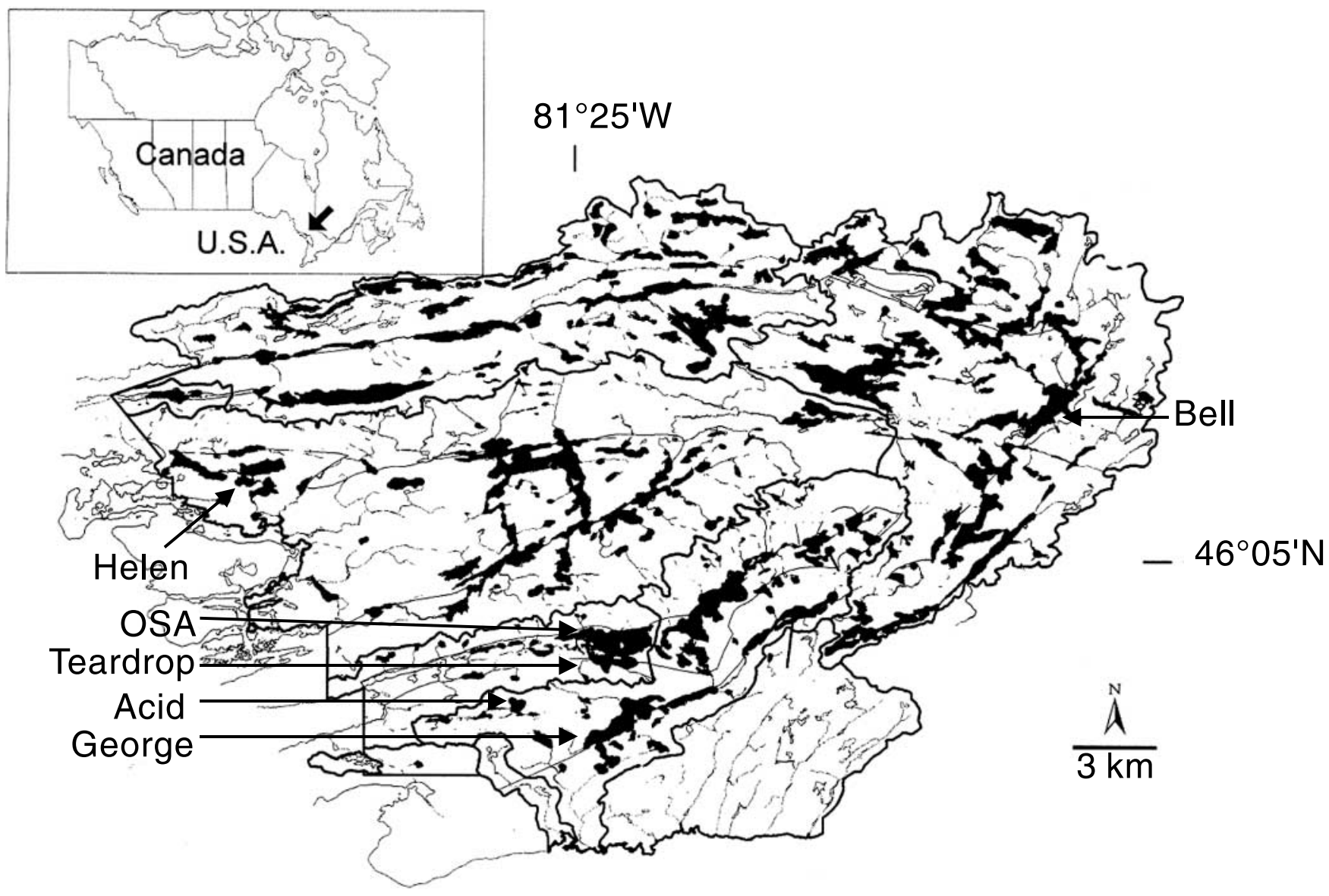

Table 1. Select chemical and physical characteristics of the six Killarney study lakes.

\begin{tabular}{|c|c|c|c|c|c|c|c|c|c|c|}
\hline Lake & $\begin{array}{l}\text { Elevation } \\
(\mathrm{m})\end{array}$ & $\begin{array}{l}\text { Lake surface } \\
\text { area (ha) }\end{array}$ & $\begin{array}{l}\text { Volume } \\
\left(10^{4} \mathrm{~m}^{3}\right)\end{array}$ & $\begin{array}{l}\text { Maximum } \\
\text { depth }(m)\end{array}$ & $\begin{array}{l}\text { Total } \\
\text { catchment } \\
\text { (ha) }\end{array}$ & $\mathrm{pH}$ & $\begin{array}{l}\text { Pre-1880 } \\
\text { diatom-inferred } \\
\mathrm{pH}\end{array}$ & $\begin{array}{l}\mathrm{DOC}^{*} \\
\left(\mathrm{mg} \cdot \mathrm{L}^{-1}\right)\end{array}$ & $\begin{array}{l}\text { Total } \\
\text { nitrogen } \\
\left(\mu \mathrm{g} \cdot \mathrm{L}^{-1}\right)\end{array}$ & $\begin{array}{l}\text { Total } \\
\text { phosphorus } \\
\left(\mu \mathrm{g} \cdot \mathrm{L}^{-1}\right)\end{array}$ \\
\hline Acid & 275 & 19.6 & 213 & 29.0 & 463.8 & 5.1 & 5.6 & 0.4 & 160 & 5.6 \\
\hline George & 189 & 189 & 3086 & 36.6 & 5716.7 & 6.2 & 6.1 & 1.4 & 160 & 12.2 \\
\hline Bell & 221 & 347 & 2827 & 26.8 & 8596.3 & 6.1 & 6.0 & 3.9 & 320 & 17.6 \\
\hline
\end{tabular}

Note: Lakes were sampled using a 5-m integrating tube on 2-3 November 1998.

$*$ DOC $=$ dissolved organic carbon.

and wetlands. Similarly, George Lake is surrounded mainly by mixed forest $(\sim 60 \%)$ and overlies the contact between high northern outcrops of orthoquartzite and siltstone and southern outcrops of granite and sedimentary rock. Helen Lake and Teardrop Lake were included as circumneutral reference sites that currently have $\mathrm{pH}$ readings that are comparable to diatom-inferred pre-1880 values (Table 1). Helen Lake has a relatively small catchment underlain by conglomerate bedrock consisting of limestone, diabase, and sandstone, along with glacial deposits and $\sim 60 \%$ vegetation cover. Teardrop Lake is perched on an orthoquartzite ridge, but is well buffered because of an intrusion of calcium- bearing diabase within its catchment. The very small catchment of Teardrop Lake is composed of $\sim 50 \%$ mixed forest and $\sim 25 \%$ exposed rock.

\section{Sediment analyses}

Sediment cores were recovered from the deepest central portion of each lake during February 1999 using a Glew Maxi gravity corer and extrusion device (Glew 1989). The cores were sectioned at close intervals $(0.5-\mathrm{cm}$ intervals for top $5 \mathrm{~cm} ; 1.0-\mathrm{cm}$ intervals for bottom $30 \mathrm{~cm}$ ). The cores were dated by measuring the ${ }^{210} \mathrm{~Pb}$ activity in the sediment samples using a low-background Gamma detector at the 
Paleoecological Environmental Assessment and Research Laboratory (PEARL) of Queen's University (Kingston, Ont.). Subsamples of sediment for pigment analysis were frozen and stored in the dark until pigment extraction. Although we analyzed only one core from each lake, quality assurance studies have shown that single cores collected from the middle of deep-basin lakes can provide representative samples for paleolimnological analyses (e.g., Renberg and Battarbee 1990).

Sedimentary pigment concentrations were quantified using a standard reversed-phase, high-pressure, liquid chromatography (HPLC) procedure (Vinebrooke and Leavitt 1998). Pigments were extracted by soaking freeze-dried sediments in acetone, methanol, and water $(80: 15: 5 \mathrm{v} / \mathrm{v})$ for $24 \mathrm{~h}$ in darkness at $10^{\circ} \mathrm{C}$. Extracts were filtered through $0.2-\mu \mathrm{m}$ pore nylon filters, dried, and stored under nitrogen gas in the dark at $-20^{\circ} \mathrm{C}$. Dried extracts were reconstituted using injection solution (70\% acetone: $25 \%$ ion-pairing reagent: $5 \%$ methanol) containing Sudan II $\left(3.2 \mathrm{mg} \cdot \mathrm{L}^{-1}\right)$ as an internal reference. Ion-pairing reagent consisted of $0.75 \mathrm{~g}$ tetrabutylammonium acetate and $8 \mathrm{~g}$ ammonium acetate in $100 \mathrm{~mL}$ deionized water. Pigments were separated on a HewlettPackard (Hewlett-Packard Canada Ltd., Mississauga, Ont.) model 1100 system with a Rainin Model 200 C-18 column (10-cm length, 5- $\mu \mathrm{m}$ particle size). Pigments were detected with an inline HP Series 1100 diode array detector (435-nm detection wavelength) and a fluorescence detector (435-nm excitation wavelength, 667-nm detection wavelength). Analytical separation involved isocratic delivery $\left(1.0 \mathrm{~mL} \cdot \mathrm{min}^{-1}\right)$ of a mobile phase A (10\% IPR in methanol) for $1.5 \mathrm{~min}$, a linear succession to $100 \%$ solution $\mathrm{B}(27 \%$ acetone in methanol) over $7 \mathrm{~min}$, and isocratic hold for $12.5 \mathrm{~min}$. The column was re-equilibrated by continued isocratic delivery for 3 min, a linear return to $100 \%$ solution A over 3 min, and isocratic delivery for a final $4 \mathrm{~min}$. Pigment concentrations were quantified using equations derived from dilution series of authentic standards supplied by the United States Environmental Protection Agency (USEPA, National Exposure Research Laboratory, Cincinnati, Ohio), or commercial standards (Sigma Chemicals, St Louis, Mo.). All pigment concentrations were expressed per gram organic matter, which was determined by weight lost on ignition $\left(500^{\circ} \mathrm{C}\right.$ for $\left.2 \mathrm{~h}\right)$.

Whole-lake algal abundance and gross community composition were inferred from concentrations of undegraded chlorophylls (chl $a, b$, and $c$ and total chl) and taxonomically diagnostic carotenoids (Jeffrey and Vesk 1997). Major algal groups identified included chlorophytes (chl $b$, pheophytin $b$, lutein), chl $c$ producing chromophytes (chrysophytes, diatoms, and dinoflagellates such as diadinoxanthin, diatoxanthin, and fucoxanthin), cryptophytes (alloxanthin), and cyanobacteria (zeaxanthin), including select filamentous forms (canthaxanthin). Lutein could not be separated from zeaxanthin, so HPLC analyses of $b$-phorbins were used to determine the relative abundance of chlorophytes. Pigments were identified by comparison of profiles of spectral absorbance and chromatographic mobility with USEPA authentic standards and extracts of known pigment composition. Sedimentary pigments were not used to infer wholelake algal productivity or production because cellular pigment concentrations and photosynthetic rates can be decoup- led by various factors (e.g., cell cycle, nutrient status, and irradiance).

\section{Statistical analyses}

For each lake core, differences between pre- and postindustrial total chlorophyll and carotenoid concentrations and their variances were tested for using $t$ tests and $Z$ tests of coefficients of variation, respectively. Smelter activities in nearby Sudbury had become very active by 1900 (HowardWhite 1963); therefore, this year was used to differentiate ${ }^{210} \mathrm{~Pb}$-dated lake cores into pre- and post-industrial sediment intervals. Surface-sediment samples and samples associated with transition years (1890-1910) were excluded from statistical analyses to minimize the confounding effect of pigment diagenesis and establish clear temporal separation between pre- and post-industrial eras. Pigment data were inspected for normal distributions prior to statistical analysis, and logarithmic transformations performed when necessary. Coefficient of variation $(\mathrm{CV})$ was used as a measure of temporal variability because, unlike other measures of variability (e.g., variance, standard deviation), it was independent of the mean. To avoid temporal pseudoreplication (Hurlbert 1984) and violation of the statistical assumption of sample independence when analyzing each core, significance of actual $t$ test and $Z$ test values was determined using randomization testing (Manly 1997). Stratigraphic pigment concentrations were randomly assigned (999 permutations) to either before or after the year 1900, and the approximate $P$ value was determined by the number of times the randomly generated test statistics exceeded the observed values based on analyses of the original data.

Correspondence analysis (CA) was used to ordinate concentrations of major taxonomically diagnostic chlorophylls and carotenoids and ${ }^{210} \mathrm{~Pb}$-dated samples from each lake sediment core. CA summarized the maximum amount of variation in the pigment data and constructed primary ( $x$ axis) and secondary ( $y$ axis) environmental and temporal gradients along which pigments and sediment samples were ordered. Specifically, ${ }^{210} \mathrm{~Pb}$-dated samples that contained similar pigment concentrations appeared closer together in ordinate space than did samples with very different pigment compositions. Also, the proximity of pigments to ${ }^{210} \mathrm{~Pb}$-dated samples in ordinate space represented how closely they are associated. For example, a post-industrial sediment sample that occurred close to chl $b$ in a CA plot would have contained a high concentration of that pigment. All pigment data were $\ln (x+1)$ transformed, but not weighted prior to CA. Pigment scores were weighted by mean sample scores to scale ordination scores. Ordinations were performed using the computer program CANOCO version 3.12 (ter Braak 1990).

\section{Results}

\section{Whole-lake algal abundance}

Post-industrial (ca. 1900) sedimentary pigment concentrations increased significantly by $50-300 \%$ in five of the six study lakes (Fig. 2; Table 2). The most significant increases in total chlorophyll and carotenoid concentrations occurred after 1940 in the cores retrieved from the heavily acidified clearwater lakes (Acid and OSA). Similarly, post-industrial 
Fig. 2. Temporal patterns of total sedimentary carotenoid $(\bullet)$ and chlorophyll $(\bigcirc)$ concentrations in $(a)$ Acid Lake, $(b)$ OSA Lake, (c) George Lake, (d) Bell Lake, (e) Teardrop Lake, and ( $f$ ) Helen Lake of Killarney Provincial Park, Ont. The onset of industrial deposition over the lakes (ca. 1900) is indicated by dashed vertical lines.
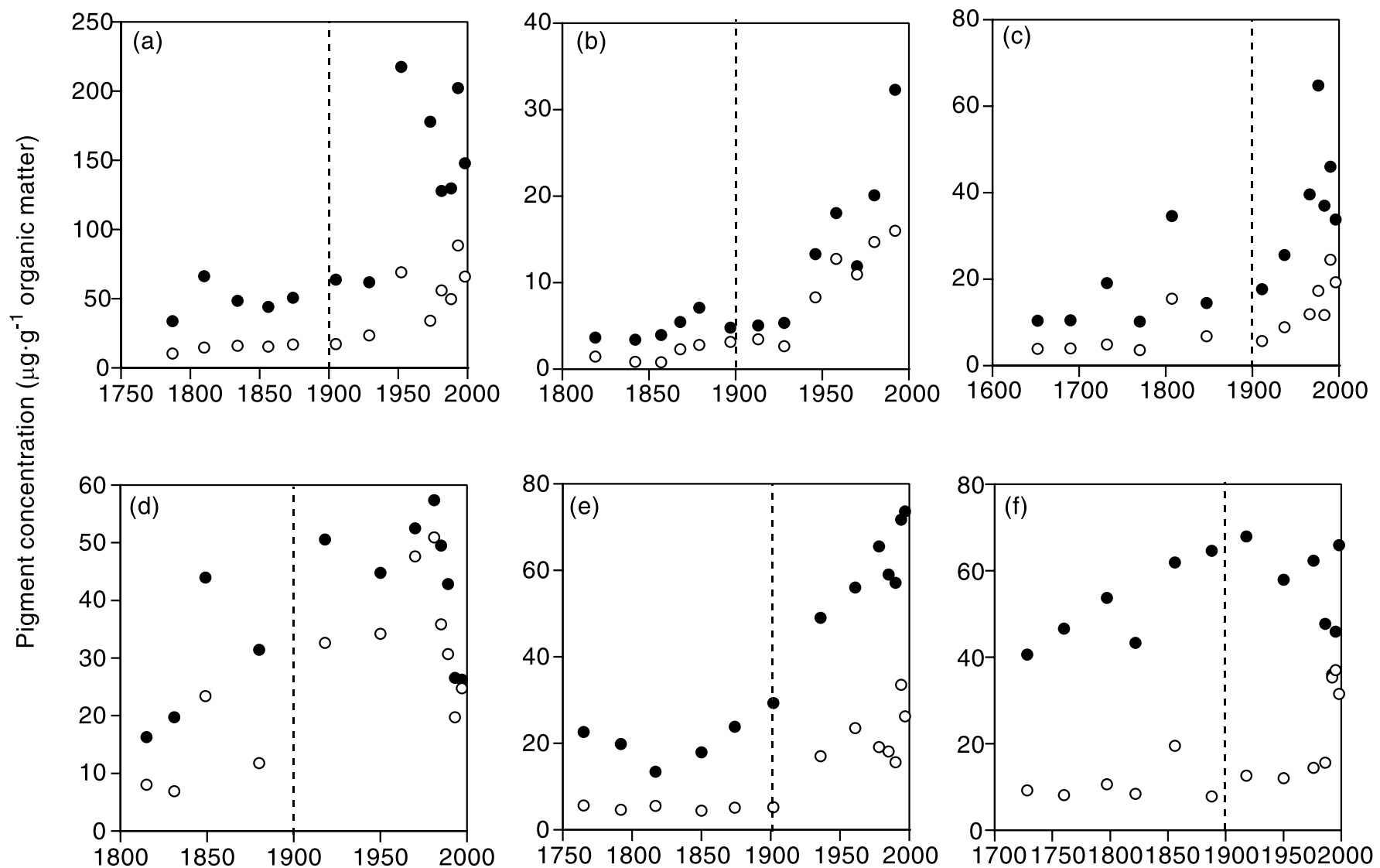

Table 2. Comparisons of pre- and post-industrial mean total chlorophyll and carotenoid concentrations in sediment cores from six Canadian lakes located in a region of high acid deposition.

\begin{tabular}{lcc}
\hline Lake & Chlorophylls & Carotenoids \\
\hline Acid & $17.12 * * *$ & $28.94 * * *$ \\
OSA & $7.13 * * *$ & $6.81 * * *$ \\
George & $6.28 * *$ & $9.45 * * *$ \\
Bell & $13.67 * * *$ & $7.07 * * *$ \\
Teardrop & $22.98 * * *$ & $54.96 * * *$ \\
Helen & 1.61 & 0.18 \\
\hline
\end{tabular}

Note: Significance of difference between two means was determined using randomization testing (999 permutations) of $t$ values. **, $P<0.01 ; * * *, P<0.001$.

pigment concentrations were significantly higher in the recovering acidified lakes (George, Bell), and in a circumneutral reference site (Teardrop Lake). Chlorophyll $b$ concentrations were also higher in post-industrial sediments in Acid Lake, OSA Lake, George Lake, and Bell Lake (Fig. 3a). In contrast, pre- and post-industrial sedimentary pigment concentrations were not significantly different in the other reference site, namely Helen Lake (Figs. 2 and $3 a$ ).
Year

Concentration ratios of total undegraded chlorophylls to chlorophyll derivatives (pheophytins $a, b$ ) were not related significantly to $\mathrm{Pb}^{210}$-inferred sediment age, which confirmed that lower pre-industrial pigment concentrations were not attributable to pigment diagenesis (Fig. 3b). Relative temporal variability of pigment-inferred whole-lake algal abundance in the six study lakes did not change significantly after 1900 (Figs. 2 and 4). Sediments from all study lakes lacked visible laminae, which prevented finer inter-annual resolution of the pigment stratigraphies.

\section{Whole-lake algal community structure}

Sedimentary pigment signatures of five of the six lakes changed following the onset of industrial deposition (ca. 1900 AD) over the study area (Figs. 4 and 5). In general, higher post-industrial concentrations of sedimentary chlorophylls and carotenoids in the Killarney lakes were primarily attributable to increases in chl $b$, alloxanthin, and fucoxanthin. Chlorophyll $b$ and alloxanthin represented reliable taxonomic signatures because they are major specific pigments $(>10 \%$ of total cellular chlorophylls or carotenoids) of chlorophytes and cryptophytes, respectively (Jeffrey and Vesk 1997). However, the taxonomic resolution of fucoxanthin, diadinoxanthin, and diatoxanthin were rela- 
Fig. 3. Temporal patterns of (a) sedimentary chlorophyll $b$ concentrations, and $(b)$ total undegraded chlorophyll to pigmented derivative (pheophytin $a$ and $b$ ) concentration ratios in six Killarney lakes. Onset of industrial deposition over the lakes (ca. 1900) is indicated by dashed vertical lines.

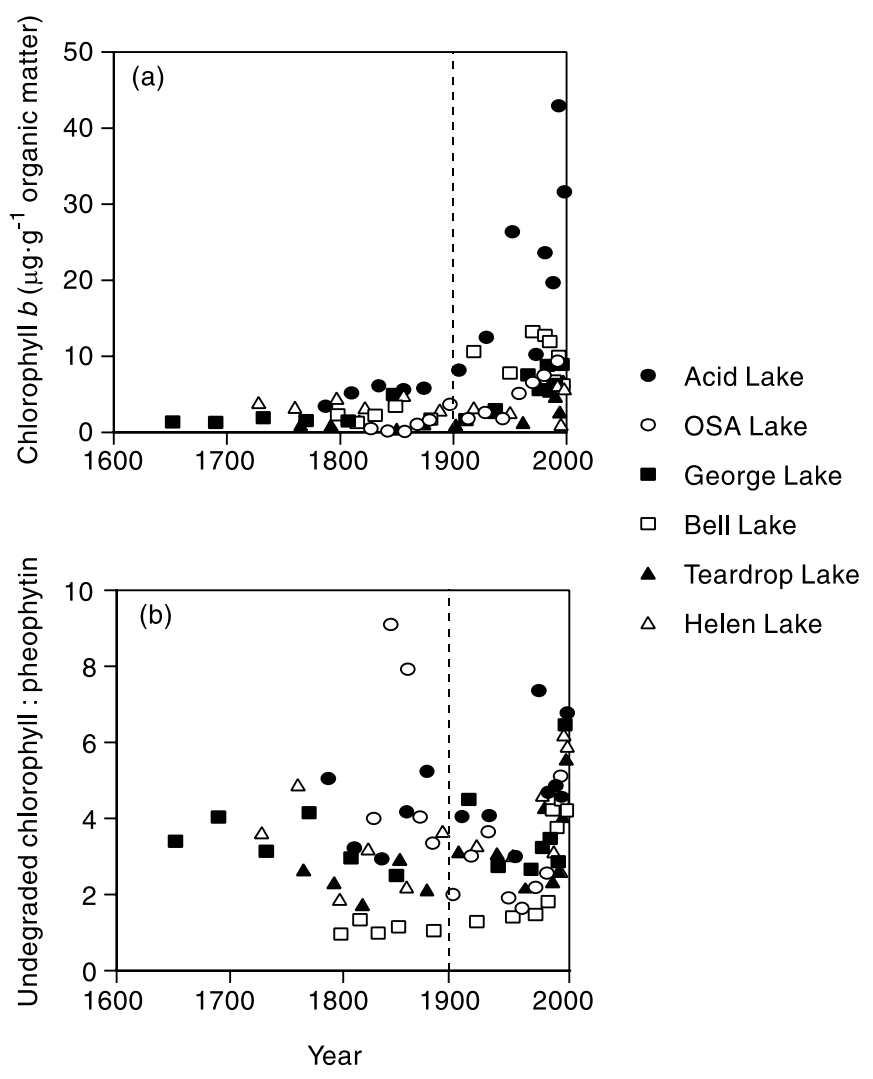

tively poor because these pigments are produced by most chl $c$ containing chromophytes, such as chrysophytes, diatoms, and certain dinoflagellates (Jeffrey and Vesk 1997).

In Acid Lake, increased post-industrial total carotenoid concentrations were primarily attributable to higher alloxanthin levels starting around 1929 (Fig. 4). CA of the sedimentary data accounted for $84 \%$ of the variance in the pigment concentrations with its first two axes, and separated pre- and post-industrial pigment signatures (Fig. 5). After 1929, the pigment signal became more variable in Acid Lake and shifted towards the upper right quadrant of the ordinate axes, which was associated with higher concentrations of pigments, such as cryptophycean alloxanthin and chlorophycean chl $b$ (Fig. 5).

In OSA Lake, increased fucoxanthin, diatoxanthin, and lutein-zeaxanthin concentrations mainly accounted for a significant increase in total carotenoid levels after 1900 (Fig. 4). The first two CA axes captured $82 \%$ of the variance contained within the pigment data, and showed that pigment signatures began to shift towards higher concentrations of chl $b$ and fucoxanthin between 1913 and 1946 (Fig. 5). The trajectory of ${ }^{210} \mathrm{~Pb}$-dated sediment scores for OSA Lake also showed greater relative variability and no reversal back to pre-industrial scores since 1913 (Fig. 5).

In George Lake, higher post-industrial total carotenoid concentrations consisted primarily of alloxanthin and fucoxanthin (Fig. 4). CA axes 1 and 2 extracted $75 \%$ of the total variance in the sedimentary pigment data, and contrasted pre- and post-industrial sediments on the basis of disproportionate increases in alloxanthin, fucoxanthin, and chl $b$ concentrations since 1911 (Fig. 5). Although total sedimentary carotenoid concentrations in George Lake have declined over the past decade (Fig. 4), pigment signatures have continued to move from left to right in ordinate space (Fig. 5).

In Bell Lake, higher post-industrial total carotenoid concentrations resulted mainly from increases in alloxanthin and fucoxanthin (Fig. 4). CA axes 1 and 2 accounted for $81 \%$ of the total variance contained within the pigment data set, and contrasted pre- and post-industrial pigment signatures (Fig. 5). In general, pigment signatures have moved downward into the lower left-hand quadrant of ordinate space from 1880 to 1970 , with a slight return to the right since 1985 owing to recent declines in alloxanthin and fucoxanthin concentrations to pre-industrial levels (Fig. 5).

In Teardrop Lake, post-industrial total carotenoid concentrations increased owing to higher concentrations of alloxanthin, diatoxanthin, lutein-zeaxanthin, and fucoxanthin (Fig. 4). The first two CA axes captured $89 \%$ of the total variance of the pigment data, and separated pre- and postindustrial pigment signatures based on higher concentrations of most pigments, except canthaxanthin, in sediments after 1902 (Fig. 5). Lake scores moved right in ordinate space from 1902 to 1994, and remained displaced from the preindustrial scores that occur in the left side of the plot (Fig. 5). Trace-metal concentrations also increased in postindustrial sediments, whereas diatom-inferred $\mathrm{pH}$ remained relatively stable in Teardrop Lake (Fig. 6).

In Helen Lake, pigment signatures have remained relatively unchanged over the past 300 years, except for a recent, but temporary, decline in alloxanthin in near-surface pigments (Fig. 4). Before 1976, lake scores showed little variation in ordination space (Fig. 5). Recent variation of lake scores occurred because of higher concentrations of undegraded chl $b$ and recent declines in alloxanthin since 1976 (Figs. 4 and 5).

\section{Discussion}

Our study provides paleolimnological evidence of increased pigment-inferred algal abundance in five of six Killarney lakes following the onset of acidic industrial deposition over central Ontario. Specifically, higher post-industrial sedimentary pigment concentrations in the four acidified lakes (Acid, OSA, George, Bell) suggested that whole-lake algal abundance increased as a result of anthropogenic acidification. In addition, pigment concentrations also increased significantly in a small, circumneutral reference site (Teardrop Lake) over the last century. In contrast, our findings suggested that whole-lake algal abundance had remained relatively unchanged in a larger, circumneutral site (Helen Lake) over the past 300 years. Sedimentary pigment stratigraphies in the six lakes could not have involved temporal changes in macrophyte or terrestrial vegetation because both are relatively sparse in the study area (R. Vinebrooke, personal observation). Instead, changes in sedimentary pigment signatures in the five Killarney lakes can be linked to temporal and spatial shifts in whole-lake algal community structure. 

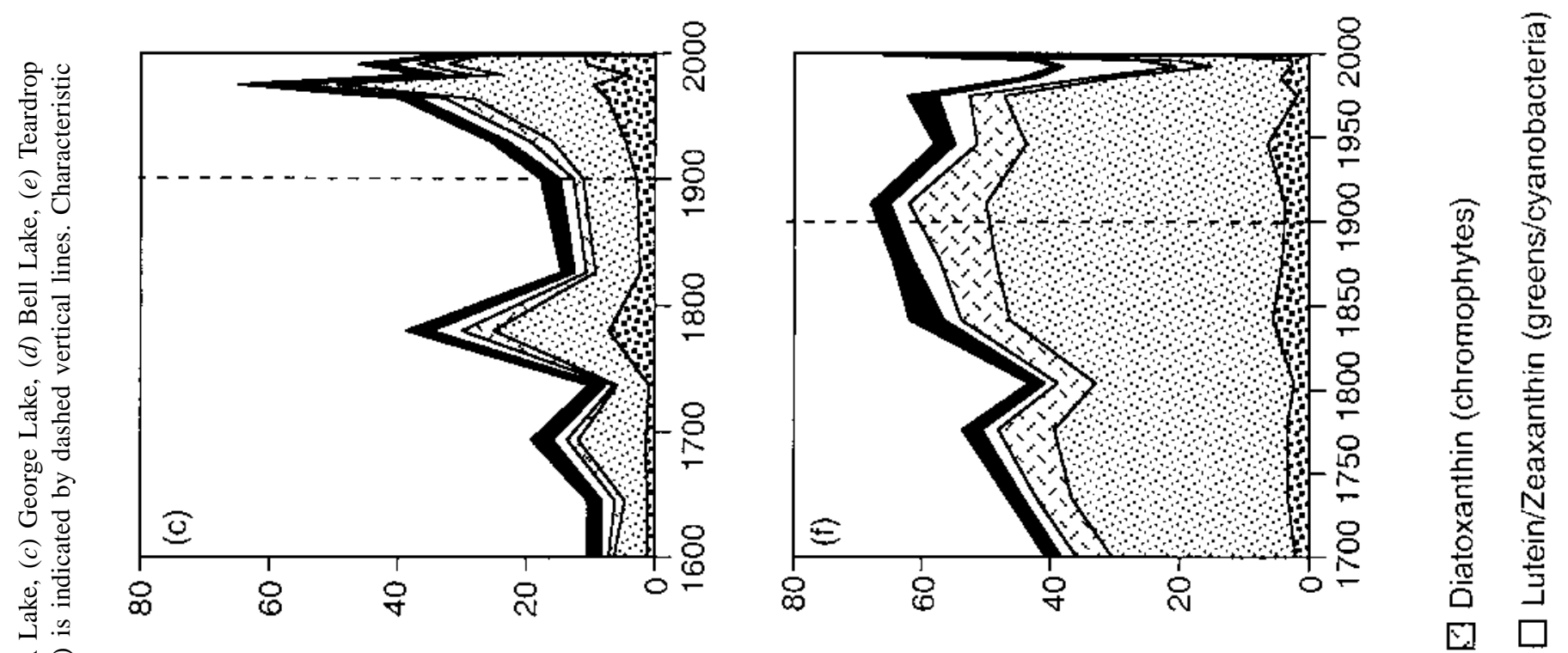

«๐ิ

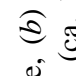
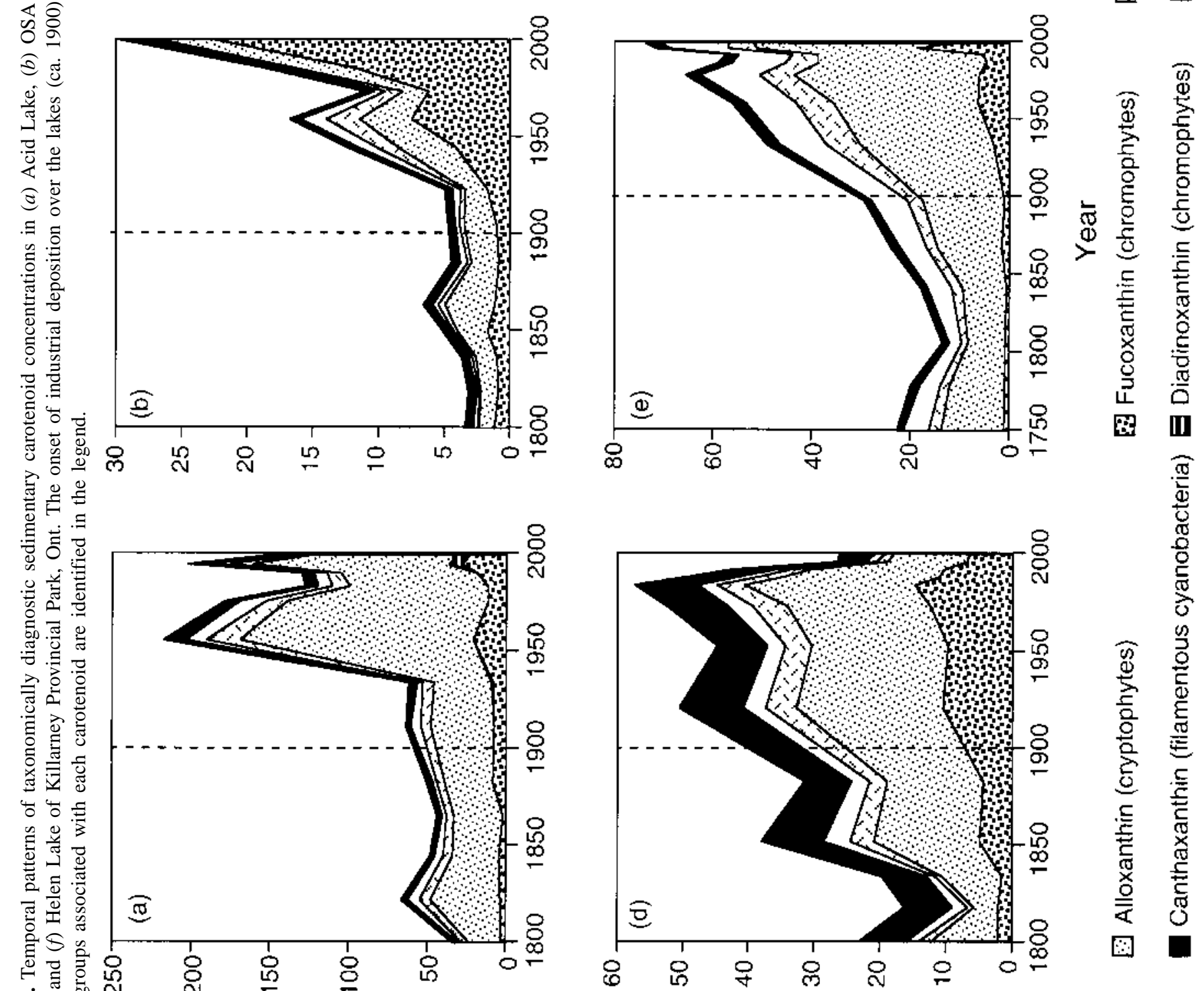

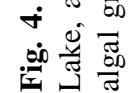

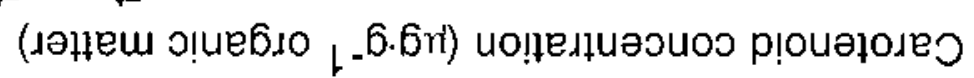


Fig. 5. Ordination diagrams based on correspondence analysis (CA) of taxonomically diagnostic pigment concentrations $(-)$ in ${ }^{210} \mathrm{~Pb}$ aged lake sediment cores ( $\boldsymbol{\square}$, pre-industrial sediment intervals; $\square$, post-industrial sediment intervals) showing temporal trajectories of (a) Acid Lake, $(b)$ OSA Lake, $(c)$ George Lake, $(d)$ Bell Lake, $(e)$ Teardrop Lake, and $(f)$ Helen Lake. Abbreviations: Allo, alloxanthin; Canth, canthaxanthin; Chl $b$, chlorophyll $b$; Diato, diatoxanthin; Fuco, fucoxanthin; Lut/Zea, lutein/zeaxanthin.
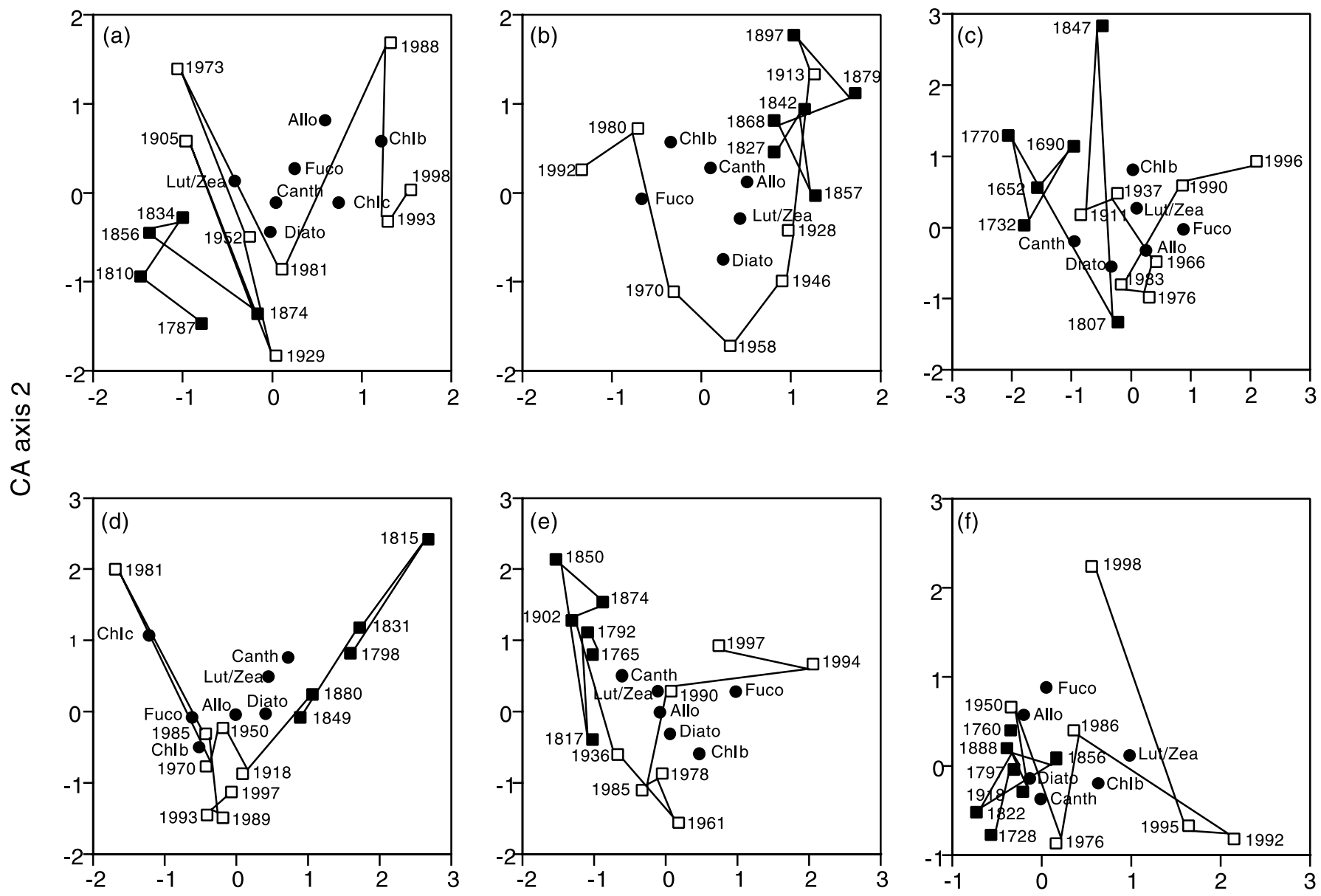

CA axis 1

Sedimentary pigment-inferred increases in post-industrial algal abundance in the acidified Killarney lakes possibly resulted from enhanced blooms of deepwater phytoplankton. The rationale for this explanation is based on evidence of increased metalimnetic and hypolimnetic phytoplankton abundances, but not primary productivity, in three experimentally acidified lakes (Schindler et al. 1991). Similarly, postindustrial increases in sedimentary alloxanthin and fucoxanthin concentrations in Acid Lake, OSA Lake, George Lake, and Bell Lake are consistent with increased abundances of deepwater phytoflagellates, namely cryptophytes, chrysophytes, and some dinoflagellates. Deepwater phytoplankton consists of facultative photoautotrophic species that must cope with light limitation, and therefore, contain relatively high concentrations of chlorophylls and accessory pigments (St. Amand and Carpenter 1993). Therefore, leaching of light-attenuating DOC by acid deposition in boreal lakes (Schindler et al. 1996; Yan et al. 1996) could have increased light availability and the abundance of deepwater algae in the Killarney lakes. For example, diatom-inferred DOC concentrations declined from $2.5 \mathrm{mg} \cdot \mathrm{L}^{-1}$ to $1.2 \mathrm{mg} \cdot \mathrm{L}^{-1}$ during the acidification of George Lake from 1920 to 1970 (Dixit et al. 2001), which would have substantially increased underwater light penetration. Motile phytoflagellates, such as chrysophytes, cryptophytes, and dinoflagellates, can also avoid increased penetration of damaging UVB radiation (Schindler et al. 1996; Yan et al. 1996) and seek refuge in the less-acidic, nutrient-rich hypolimnion of acidified boreal lakes (Findlay et al. 1999). Similar increases in sedimentary chlorophyll and fucoxanthin concentrations also accurately recorded enhanced blooms of deepwater chrysophytes in Lake 302S during experimental acidification from $\mathrm{pH} 6.8$ to 4.7 (Leavitt et al. 1999).

Another potential explanation for pigment-inferred increases in whole-lake algal abundances in the severely acidified lakes (Acid, OSA) involves release from grazing pressure. Specifically, herbivorous copepods and cladocerans are suppressed significantly by anthropogenic acidification below $\mathrm{pH} 5$, whereas algal biomass is more resilient to increased acidity (Findlay et al. 1999; Klug et al. 2000). However, pigmentinferred increases in post-industrial phytoplankton biomass in the acidified Killarney lakes were likely not attributable to epilimnetic algae because epilimnetic chlorophyll concentrations are unaffected by lake acidity (Schindler et al. 1991). 
Fig. 6. Sedimentary stratigraphies of lead ( $\mathbf{\square})$, nickel $(\bigcirc)$, and zinc $(\square)$ concentrations and diatom-inferred $\mathrm{pH}$ values (solid line) in Teardrop Lake, Killarney Park, Ont. The onset of industrial deposition over the lakes (ca. 1900) is indicated by dashed vertical lines. Details of field and laboratory methods are presented in Dixit et al. (2001).

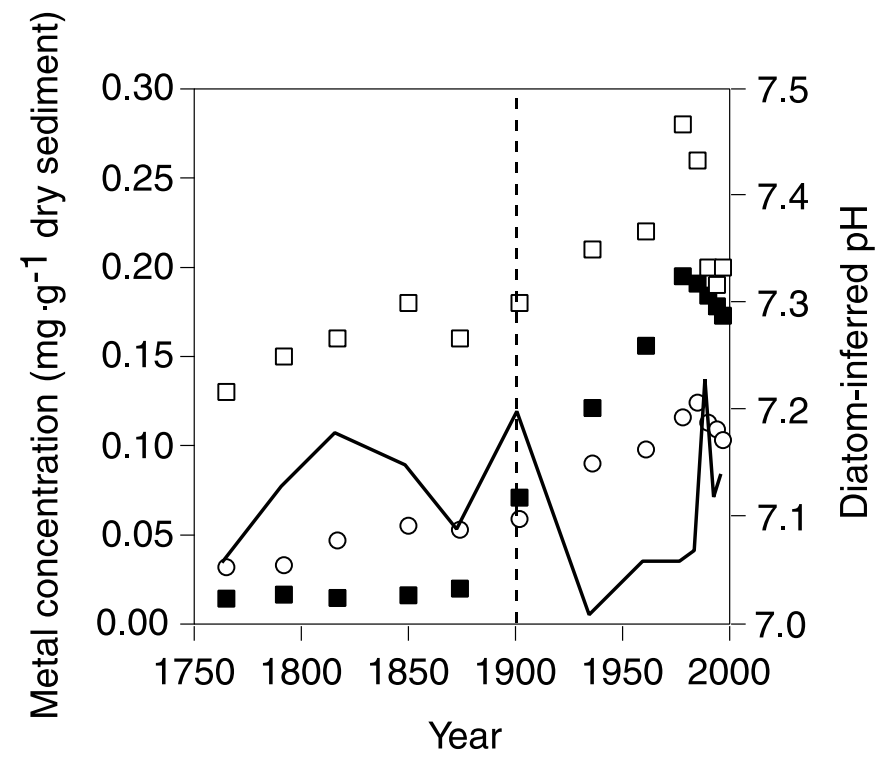

Nevertheless, epilimnetic algal biovolume did increase significantly in experimentally acidified Lake $302 \mathrm{~S}$ owing to a size shift towards large-celled dinoflagellates (Findlay et al. 1999). Unfortunately, our analyses could not accurately detect dinoflagellate responses to biotic and abiotic changes in the acidified Killarney lakes because their taxonomically diagnostic pigment (peridinin) is highly labile and poorly preserved in lake sediments (Hurley and Garrison 1993).

The characteristic proliferation of filamentous green algae in the littoral zones of anthropogenically acidified lakes (Turner et al. 1995; Vinebrooke et al. 2001) also likely contributed to pigment-inferred increases in post-industrial algal abundance in the acidified Killarney lakes. In particular, increased sedimentary chl $b$ concentrations in Acid Lake, OSA Lake, George Lake, and Bell Lake after 1900 suggested that green algae became more abundant in these lakes following the onset of acid deposition. Diatom-inferred $\mathrm{pH}$ reconstructions for Acid Lake and George Lake show that $\mathrm{pH}$ values fell below 6 between 1900 and 1920 (Dixit et al. 1992a, 2001), which corresponds with pigment-inferred increases in acidophilic green algae in both lakes. Filamentous zygnematacean algae (Mougeotia, Spirogyra, Zygogonium) flourish in the absence of benthic grazers in the littoral zone of acidified lakes, as they are superior competitors (Vinebrooke 1996; Graham and Vinebrooke 1998) for dissolved inorganic carbon (DIC), which increasingly limits phytobenthic production in lakes below pH 6 (Turner et al. 1991). Post-industrial increases in filamentous green algae in the acidified lakes possibly also resulted from the extirpation of acid-sensitive zoobenthos such as snails and tadpoles, which are effective grazers of the early developmental stages of these algae in circumneutral Killarney lakes (Vinebrooke 1996; Graham and Vinebrooke 1998). Pigment-inferred post-industrial increases in green algal abundance in the acidified Killarney lakes could not result from increases in phytoplankton biomass because it is mainly composed of chrysophytes, cryptophytes, and dinoflagellates in boreal lakes. Increases in filamentous green algae in the Killarney lakes and in the experimentally acidified Lake 302S (Leavitt et al. 1999) were better recorded by chl $b$ than by luteinzeaxanthin, possibly because increases in chlorophycean lutein were offset by declines in cyanobacterial zeaxanthin.

Diatom-inferred declines in UVB-attenuating DOC in the acidified Killarney lakes (Dixit et al. 2001) were not recorded by increases in UV-absorbing pigment concentrations in the sediment cores. In contrast, sediment-dwelling cyanobacteria produced UV-absorbing pigments (e.g., scytonemin) in response to an 8-fold increase in the penetration of UVB radiation in Lake $302 \mathrm{~S}$ as it was acidified from $\mathrm{pH} 6.8$ to 5.1 (Leavitt et al. 1997). The absence of UV-absorbing pigments in acidified Killarney lakes might be attributed to the inability of these sediment-dwelling, filamentous cyanobacteria to tolerate high acidity and inhabit the shallow littoral habitats of the heavily acidified Killarney lakes, which are composed mainly of rocky substrate (Vinebrooke 1996; Vinebrooke and Graham 1997). The expected lack of cyanobacteria in the highly acidified Killarney lakes (Acid Lake, OSA Lake, and George Lake) was supported by low concentrations of canthaxanthin, which is an indicator of filamentous cyanobacteria (Jeffrey and Vesk 1997). Interestingly, UVabsorbing pigment concentrations in Lake $302 \mathrm{~S}$ also declined as the lake was acidified below pH 5 despite further increases in underwater UVB irradiance (Leavitt et al. 1999).

Pigment-inferred increases in post-industrial total algal abundance in circumneutral Teardrop Lake might be attributed to aeolian (windblown) nutrient inputs, but not anthropogenic acidification. Paleolimnological reconstruction of the water chemistry of Teardrop Lake using diatoms showed that $\mathrm{pH}$ varied between 7.0 and 7.3 over the last 400 years. However, 3-fold increases in sedimentary trace element concentrations in Teardrop Lake since 1875 revealed that this small headwater lake was strongly influenced by aeolian dust associated with smelting activities. Aeolian dust arising from human disturbance of land surfaces and fly ash can represent a substantial source of trace elements, including phosphorus, to small waterbodies at high elevations (Reynolds et al. 2001). Because many circumneutral boreal lakes are likely phosphorus limited, and because Teardrop Lake receives only limited allochthonous inputs of phosphorus given its small catchment, this little lake is likely very responsive to aerial deposition. Interestingly, there has also been a taxonomic shift by the diatom assemblage in Teardrop Lake, which shows an onset of more productive conditions since 1930 (S.S. Dixit, unpublished data). In contrast, the fertilizing effects of long-range aeolian inputs on the other Killarney lakes (Acid, Bell, George, Helen, OSA) were likely diluted by their larger water volumes and outweighed by allochthonous nutrient inputs from relative vast watersheds. In addition, other regional processes (e.g., climate change) over the past century may also have contributed to synchronous changes in whole-lake algal community structure in Teardrop Lake and the acidified Killarney lakes. For instance, climate change has resulted in phytoplankton showing temporally coherent taxonomic patterns in other boreal lakes over the past 30 years (Findlay et al. 2001). 
Recent declines in total sedimentary pigment concentrations and shifts in pigment signatures in acidified George Lake and Bell Lake may be indicative of chemical and biological recovery since the mid-1980s. In both lakes, chemical recovery over the last two decades has enabled them to almost re-establish their historical (diatom-inferred) $\mathrm{pH}$ of 6 (Dixit et al. 2001), which also represents the threshold for the proliferation of filamentous green algae in the littoral zone of acid-sensitive boreal lakes (Turner et al. 1991). Therefore, lower carotenoid and chl $b$ levels in surface sediments of Bell Lake and George Lake may be partly attributed to the decline of acidophilic filamentous green algae. In addition, DOC levels in George Lake have increased since the 1980 s to pre-1920 inferred values (Dixit et al. 2001), which would decrease the availability of light and dampen deepwater phytoplankton blooms. Chemical recovery has also allowed many acidified Killarney lakes to be recolonized by extirpated herbivores, which can further suppress algal blooms (Vinebrooke 1996). Similar transient declines in near-surface sedimentary carotenoid concentrations in circumneutral Helen Lake suggest that other regional factors, such as climate (Findlay et al. 2001), are also affecting algal community structure in the Killarney lakes in addition to chemical recovery from cultural acidification.

Inferences of changes in whole-lake algal community structure in the Killarney lakes based on sedimentary pigment stratigraphies are potentially complicated by several factors of pigment deposition. For example, phytoplankton depth can have a positive effect on pigment deposition in lakes because of a reduction in pigment loss associated with abiotic and biotic processes (Hurley and Garrison 1993). Downward shifts in algal distribution from the epilimnion to the metalimnion may result in several-fold increases in pigment deposition (Cuddington and Leavitt 1999), which confound inferences of increased whole-lake algal abundance based on higher sedimentary pigment concentrations. Therefore, concomitant increases in total pigment concentrations and in pigment signatures of deepwater phytoplankton in the acidified Killarney lakes may reflect both enhanced wholelake algal abundance and better preservation of pigments. Herbivory can also have a positive effect on pigment deposition if digestive loss of pigments is low, and compaction of pigments into fecal material reduces the oxidative losses that mainly occur in the epilimnion (Cuddington and Leavitt 1999). However, herbivore biomass declines significantly during lake acidification (R.D. Vinebrooke and M. Paterson, Freshwater Institute, Winnipeg, Man., unpublished data), and therefore, cannot account for increased pigment deposition in the four acidified study lakes. Otherwise, we restricted our interpretation of sedimentary pigment signatures to individual Killarney lakes to avoid variation in other environmental variables, such as lake morphometry and chemical stratification, which affect pigment preservation and confound between-lake comparisons of pigment stratigraphies (Cuddington and Leavitt 1999).

In summary, our findings suggest that decades of acidic industrial deposition have altered algal community structure in boreal lakes. Although it is difficult to clearly separate the relative importance of pigment-inferred changes in wholelake algal abundance from spatial shifts in algal community structure, smelter activities appeared to enhance total algal abundance by increasing representation of deepwater and benthic algae in four acidified lakes and a small circumneutral lake. As a consequence, alteration of the base of aquatic foodwebs has likely contributed to the adverse effects of industrial emissions on higher trophic levels in the Killarney lakes.

\section{Acknowledgements}

This study was supported by a Canada Foundation for Innovation New Opportunities Grant (R.D.V.), a Natural Sciences and Engineering Council of Canada (NSERC) operating grant (R.D.V.), an NSERC Collaborative Research and Development Grant (S.S.D. and J.M.G.), and the CanadaNorway Northern Lakes Recovery Study Program at Laurentian University, Sudbury, Ont.

\section{References}

Cuddington, K., and Leavitt, P.R. 1999. An individual-based model of pigment flux in lakes: implications for organic biogeochemistry and paleoecology. Can. J. Fish. Aquat. Sci. 56: 1964-1977.

Dixit, A.S., Dixit, S.S., and Smol, J.P. 1992a. Long-term trends in lake water $\mathrm{pH}$ and metal concentrations inferred from diatoms and chrysophytes in three lakes near Sudbury, Ontario. Can. J. Fish. Aquat. Sci. 49(Suppl. 1): 17-24.

Dixit, S.S., Dixit, A.S., and Smol, J.P. 1992b. Assessment of changes in lake water chemistry in Sudbury area lakes since preindustrial times. Can. J. Fish. Aquat. Sci. 49(Suppl. 1): 8-16.

Dixit, S.S., Keller, W., Dixit, A.S., and Smol, J.P. 2001. Diatominferred dissolved organic carbon reconstructions provide assessments of past UV-B penetration in Canadian Shield lakes. Can. J. Fish. Aquat. Sci. 58: 543-550.

Findlay, D.L., and Kasian, S.E.M. 1990. Phytoplankton communities of lakes experimentally acidified with sulfuric and nitric acids. Can. J. Fish. Aquat. Sci. 47: 1378-1386.

Findlay, D.L., Kasian, S.E.M., Turner, M.A., and Stainton, M.P. 1999. Responses of phytoplankton and epilithon during acidification and recovery of a lake. Freshwater Biol. 42: 159-175.

Findlay, D.L., Kasian, S.E.M., Stainton, M.P., Beaty, K., and Lyng, M. 2001. Climatic influences on algal populations of boreal forest lakes in the Experimental Lakes Area. Limnol. Oceanogr. 46: 1784-1793.

Glew, J.R. 1989. A new trigger mechanism for sediment samplers. J. Paleolimnol. 2: 241-243.

Graham, M.D., and Vinebrooke, R.D. 1998. Trade-offs between herbivore-resistance and competitiveness in periphyton of acidified lakes. Can. J. Fish. Aquat. Sci. 55: 806-814.

Howard-White, F.B. 1963. Nickel, an historical review. Longmans, Toronto.

Hurlbert, S.H. 1984. Pseudoreplication and the design of ecological field experiments. Ecol. Appl. 54: 187-211.

Hurley, J.P., and Garrison, P.J. 1993. Composition and sedimentation of aquatic pigments associated with deep plankton in lakes. Can. J. Fish. Aquat. Sci. 50: 2713-2722.

Jeffrey, S.W., and Vesk, M. 1997. Introduction to marine phytoplankton and their pigment signatures. In Phytoplankton pigments in oceanography. Edited by S.W. Jeffrey, R.F.C. Mantoura, and S.W. Wright. UNESCO publishing, Paris. pp. 37-84.

Jeffries, D.S. 1997. Canadian acid rain assessment. Vol. 3. The effects on Canada's lakes, rivers, and wetlands. Environment Canada, Burlington, Ont. 
Keller, W., Gunn, J.M., and Yan, N.D. 1992. Evidence of biological recovery in acid-stressed lakes near Sudbury, Canada. Environ. Pollut. 78: 79-85.

Klug, J.L., Fischer, J.M., Ives, A.R., and Dennis, B. 2000. Compensatory dynamics in planktonic community responses to $\mathrm{pH}$ perturbations. Ecology, 81: 387-398.

Leavitt, P.R., Vinebrooke, R.D., Donald, D.B., Smol, J.P., and Schindler, D.W. 1997. Past ultraviolet radiation environments in lakes derived from fossil pigments. Nature (London), 388: 457-459.

Leavitt, P.R., Findlay, D.L., Hall, R.I., and Smol, J.P. 1999. Algal responses to dissolved organic carbon loss and $\mathrm{pH}$ decline during whole-lake acidification: evidence from paleolimnology. Limnol. Oceanogr. 44: 757-773.

Manly, B.J.F. 1997. Randomization, bootstrap and Monte Carlo methods in biology. Chapman and Hall, London.

Renberg, I., and Battarbee, R.W. 1990. The SWAP paleolimnology programme: a synthesis. Phil. Trans. R. Soc. Lond. B, 327: 227-232.

Reynolds, R., Belnap, J., Reheis, M., Lamothe, P., and Luiszer, F. 2001. Aeolian dust in Colorado plateau soils: nutrient inputs and recent change in source. Proc. Natl. Acad. Sci. U.S.A. 98: 7123-7127.

Schindler, D.W. 1995. Linking species and communities to ecosystem management: a perspective from the experimental lakes experience. In Linking species and ecosystems. Edited by C.G. Jones and J.H. Lawton. Chapman \& Hall, New York. pp. 313-325.

Schindler, D.W. 1998. A dim future for boreal waters and landscapes. BioScience, 48: 157-164.

Schindler, D.W., Frost, T.M., Mills, K.H., Chang, P.S.S., Davies, I.J., Findlay, D.L., Malley, D.F., Shearer, J.A.,Turner, M.A., Garrison, P.J., Watras, C.J., Webster, K., Gunn, J.M., Brezonik, P.L., and Swenson, W.A. 1991. Comparisons between experimentally and atmospherically acidified lakes during stress and recovery. Proc. R. Soc. Edinb. Sect. B, 97: 193-226.

Schindler, D.W., Curtis, P.J., Parker, B.R., and Stainton, M.P. 1996. Consequences of climate warming and lake acidification for UVB penetration in North American boreal lakes. Nature (London), 379: 705-706.

Snucins, E., and Gunn, J.M. 1998. Chemical and biological status of Killarney Park lakes (1995-1997). A study of lakes in the early stages of recovery from acidification. Ontario Ministry of Natural Resources Cooperative Freshwater Ecology Unit, Sudbury, Ont.

Snucins, E., Gunn, J.M., Keller, W., Dixit, S., Hindar, A., and Henriksen, A. 2001. Effects of regional reductions in sulphur deposition on the chemical and biological recovery of lakes within Killarney Park, Ontario, Canada. Environ. Monit. Assess. 67: 179-194.

St. Amand, A., and Carpenter, S.R. 1993. Metalimnetic phytoplankton dynamics. In The trophic cascade in lakes. Edited by S.R. Carpenter and J.F. Kitchell. Cambridge University Press, Cambridge, U.K. pp. 210-224.

ter Braak, C.J.F. 1990. CANOCO: a FORTRAN program for canonical community ordination. Microcomputer Power, Ithaca, New York.

Turner, M.A., Howell, E.T., Summerby, M., Hesslein, R.H., Findlay, D.L., and Jackson, M.B. 1991. Changes in epilithon and epiphyton associated with experimental acidification of a lake to $\mathrm{pH} 5$. Limnol. Oceanogr. 36: 1390-1405.

Turner, M.A., Robinson, G.G.C., Townsend, B.E., Hann, B.J., and Amaral, J.A. 1995. Ecological effects of blooms of filamentous green algae in the littoral zone of an acid lake. Can. J. Fish. Aquat. Sci. 52: 2264-2275.

Vinebrooke, R.D. 1996. Abiotic and biotic regulation of periphyton in recovering acidified lakes. J. North Am. Benthol. Soc. 15: 318-331.

Vinebrooke, R.D., and Graham, M.D. 1997. Periphyton assemblages as indicators of recovery in acidified Canadian Shield lakes. Can. J. Fish. Aquat. Sci. 54: 1557-1568.

Vinebrooke, R.D., and P.R. Leavitt. 1998. Direct and interactive effects of allochthonous dissolved organic matter, inorganic nutrients, and ultraviolet radiation on an alpine littoral food web. Limnol. Oceanogr. 43: 1065-1081.

Vinebrooke, R.D., Turner, M.A., Kidd, K., Hann, B., and Schindler, D.W. 2001. Truncated foodweb effects of omnivorous minnows in a recovering acidified lake. J. North Am. Benthol. Soc. 20: $697-710$.

Yan, N.D., Keller, W., Scully, N.M., Lean, D.R.S., and Dillon, P. 1996. Increased UV-B penetration in a lake owing to droughtinduced acidification. Nature (London), 381: 141-143. 